\title{
Paulo Freire: Critical, Humanist and Liberating Education (Critical Reflections on Indonesian Education)
}

\author{
Yeremias Mahur ${ }^{1, a^{*}}$, Yatim Riyanto ${ }^{1, b}$, Erny Roesminingsih $1, c$ \\ ${ }^{1}$ Department of Education Management, Postgraduate, State University of Surabaya, Surabaya, Indonesia \\ Email: a yerimahur@gmail.com; b jatimriyanto@gmail.com; c ernyroesminingsih@unesa.ac.id \\ ${ }^{*}$ Corresponding Author
}

How to Cite : Mahur, Y., Riyanto, Y., Roesminingsih, E. (2019). Paulo Freire: Critical, Humanist and Liberating Education (Critical Reflections on Indonesian Education). International Journal for Educational and Vocational Studies, 1 (8), 873-877. DOI: https://doi.org/10.29103/ijevs.v1i8.2242

\section{ARTICLE HISTORY}

Received: 13 September 2019

Revised: 8 October 2019

Accepted: 2 November 2019

\section{KEYWORDS}

Critical Education

Bank Style Education;

Silen Culture;

Hegemony;

Consientization;

\section{ABSTRACT}

This thesis presents about education concept of Paulo Freire about the education which are critical, humanist, and free. This education concept is Freire's opinion towards traditional education practice. Paulo Freire sees that education reality is an oppression reality. That is reflected in two things in the in education praxis; first, hegemony in education, which is a relation between teacher and student that is not based on humanity relation, but between a sovereign and subordinate. Teacher becomes the dominant subject in the relationship and the student is just an object. Whereas, both teacher and student are the learning subject. Second, education in bank style. Education in this model places student as an empty bottle that must be filled by the teacher. Seeing that condition, Freire proposes different concept and school praxis. That is critical education, humanist, and independence as the writer says in this thesis. The result of that education process will create a mindful human being. Freire calls it consientization. This thesis will also examine the coherence with education in Indonesia.

This is an open access article under the CC-BY-SA license.

\section{INTRODUCTION}

The problem of education is still a serious problem in developing countries including Indonesia. Various efforts carried out by the government from year to year, can be seen only able to touch the structural and operational aspects. Such as curriculum changes, teacher certification, teacher allowances, national examinations and so forth. Surely there are other efforts as with the issue of character education that is being intensified these days.

So far, education is still seen as not being able to touch on a substantial issue, namely how humans are the main point, so it is not uncommon for us to encounter complicated problems in the community is the fruit of the failure of education itself. Call it some of the complicated problems faced by this nation ranging from corruption, drug abuse, fudamentalism that lead to acts of terrorism, identity politics that adorn the political stage and hoaxes or hoaxes that adorn our daily lives.

On the other hand, we might stroking our breasts to see our students who are pinned as the next generation of the nation, but like brawl, pornography, happy narcotics, hobbies staying up late and racing, free sex and so forth. although we cannot deny that, there are still many of our students who have made achievements both at national and international levels.

Still warm in our minds, the case of a teacher beating by a student in Sampang Madura, until the teacher died (kompas.com, 3/02/2019). Or the case of kidnapping of teachers in Gresik is done by the students themselves. And of course there are still many examples of cases in our education world that reflect that something is wrong in our education process. Not to mention seeing statistics that show the low quality of our education both at national and international levels.

In 2017, when the Minister of Education and Culture issued Ministerial Regulation number 23 of 2017, full day school received strong criticism from the public. Even some people who judge, that the application of eight hours of learning a day in the regulation is a form of restraining students' freedom. Educational regulations that change like this also seem to place students only as a "rabbit" experiment and getting away from the substance of education itself.

From some of the problems above, maybe for a moment we need to reflect on the process and purpose of education itself. One of the critical pedagogues that can be used as 
references in this paper is Paulo Freire (1921-1997). He is famous for his criticism of traditional educational practices that do not heat students as learning subjects. Freire is a figure in education and social politics who fought for liberation education for the oppressed in Brazil.

This paper wants to explore and answer some basic questions about, 1) the concept of Paulo Freire education, which carries critical education, humanism and solidification, 2) the condition of the society described by Paulo Freire as a result of the critical, humanist and violent education process, and 3) the relevance of the educational concept proposed by Freire to the context of our education in Indonesia.

\section{Paulo Freire And His Life}

Paulo Freire, born in Recife on September 19, 1921. A port city in northeast Brazil. His father, Joachim Freire was a police officer and his mother was Edeltrus Neves Freire. It was from his family that Freire learned to respect dialogue and respect the choices of others. The Freire family belonged to the middle class, but because Brazil experienced a great economic depression at that time, the Freire family also experienced financial difficulties. Because of this condition, Freire is well aware of what it means to be hungry for elementary school children.

After his father died in 1931, Freire decided to devote his life to the struggle against ignorance and poverty. With the hope that, there will no longer be a generation that will feel the hunger pains that it has experienced.

In 1943, Freire continued his studies at the University of Recife, entering the Faculty of Law. In addition, he also studied philosophy, psychology and language. Because of his legal education background he had become a lawyer, however, his calling to life led him to become a pedagogue (educator). A path that solidifies its commitment to devote life to defending the oppressed.

Freire married Elza Maia Costa Olivera of Recife, in 1944. An elementary school teacher (who later became the principal). From his marriage to Elza gave birth to three daughters and two sons. It was after the marriage that Freire's instincts and concern for education began to grow, he read more books on education, philosophy and sociology than the law books that became his means of income. Until 1959, he completed his doctorate at the University of Recife with a dissertation that raised issues of education and social politics, entitled "Educacao e Atuliadde Brazileira" (education and current conditions in Brazil). Later, he was appointed professor of history and philosophy of education at the University.

Freire decided to leave the profession of lawyers and accept an offer to work in the education and culture section of "The Stete of Panumbuco". (The social services section of the state of Pernambuco). It was from this that Freire began to explore and criticize the practice of education that was very oppressive and directly interacted with the oppressed community.

The results of Paulo Freire's thoughts are poured through his phenomenal works. Some of them are
Education as the practice of freedem (1967), Pedagody of Opressed (1970) and Pedagogy of hope (1994). All of his works cannot be separated from the results of his reflection on the reality of the society he encountered.

Freire thought is inseparable from the influence of figures such as Sattre, Althusser, Mournier, Ortega Y.Gasset, Unamuno, Martin Luther King Jr., Che Guevara, Fromm, Mao Tse Tung, Marcuse and so on. Reading Freire's work, we will find similarities with the ideas of Marx and Mao in aspects of history and culture. But in the analysis of Freire's educational philosophy, it never leads to any flow. The thoughts flow a lot from their daily experiences. Based on the results of his thinking, some experts classify Freire as an idealist, communist, theologian, phenomenologist and existentialist. But as an educational figure, he is known as one of the main figures of reconstructionism.

\section{The Reality of Education According To Paulo Freire}

Freire acknowledged that in order to realize educational goals, there was never a neutral interest. In the fight it is always political. But the problem is the goal of the political interests of education, for what and who. As the experience that occurred in Brazilian society at that time. he concluded, the reality of Brazilian society is the reality of oppression. This reality is the result of the contradiction between people who Freire called the Oppressor and the Oppressed. The relationship between the two is no longer built on the basis of human values, but on the calculation of the benefits of capital and maintaining the status quo in caring for power.

Likewise, the educational portrait that Freire saw. First, education hegemony. In this case, Freire considers education only as a "tool" to perpetuate the power of the oppressor. As is the case in schools. Freire tried to dismantle the passive character of the traditional educational practices that plagued the world of education. He considered that passive education as practiced in general, basically perpetuated the "system of relations of oppression".

Furthermore, for the oppressors, humans are nothing more than "things". The oppressor considers there is only one right for them (the oppressed), namely the right to live "peace". While the fate of those who live with hunger, pain, endured grief and despair are never a burden on their minds. They only understand how to defend themselves with the comfort they find with bound their rights by the Oppressor.

Second, bank style education. This model of education according to Freire only places students like empty bottles that must be filled. Furthermore, for Freire, educational practice like this is only directed to domestification, taming, social adjustment with oppression. Education is considered a material investment to carry on the traditions and wealth of the nation for future generations. The education process will only give birth to a culture called Freire as a culture of silence (the culture of silence). The relationship between educator and educated person 
(teacher and student) is contrast and vertical. The teacher is the active subject, who is the penutan. While students are passive objects. Therefore, the identity imprinted on students must imitate the teacher's identity.

\section{Critical, Humanist And Liberating Education}

Based on the reality of such traditional educational practices, Freire offers different concepts and educational praxis, by proposing a Critical, Humanist and Liberating educational process. First, Critical education. Critical education is education that requires critical attitude and awareness. That awareness is born from each subject of education. Who is the subject of education? For Freire, both educators (Teachers) and students (students), are the subject of education itself. Critical education was born from the process of awareness of the social reality of the subject of education itself.

To arrive at the social awareness process, an education concept called Freire is needed as "problem posing education". This concept is in opposition to the concept of "bank style" education which according to Freire is inhumane and results in a mute society, not a critical society.

In its application, education faces the problem of making dialogue an absolute requirement for educational subjects in understanding and expressing reality. Each offers what they understand. Both of them build new understanding through the integration (synthesis) of their respective knowledge. There is no one who dominates (especially the teacher) to conquer the weaker. Both respect each other's knowledge.

In this case, education against a problem does not mean underestimating the teacher's knowledge. The education process is still led by teachers who have broader and more complete knowledge. Teaching science, abstract and theoretical, are not necessarily relevant for their students if they have not been able to relate it to their real world, that is where the instructor must be dismantled. Students are guided so that they see social, economic, cultural, religious and political structures not to be taken for granted but instead to be questioned. The teacher helps students criticize the unfair structural reality.

For Freire, science is not something possessed by someone, but the ability/skills to see and understand through the right language. Education is the process by which we give names to the real world.

Second, Humanist education. For Freire, humanization is the ultimate goal of education. Because, Humans are the law on him, because it has become a human nature to become an independent human being. What happened in Brazil at that time was seen as a denial of the noble goals of education itself. Humanization begins with educated care. Subjects who have consciousness, agents, and not empathetic thoughts must be met.

Third, education is free. On many occasions, Freire said that education was the most vital element for human liberation. For him, education became a permanent pathway to liberation through two stages. First, with education people become aware of the reality of oppression of themselves and their environment. Thus, through the praxis movement to change it. Secondly, education is a permanent process of cultural action for liberation and progress of civilization.

\section{Conscious Society}

Becoming aware of society is the ultimate goal of Freire's praxis. The term Freire often uses is consientization. Consciousness (consientization) is an input, process and output of the educational process. Being aware means, not being a spectator of reality whose role is only to record events. However, reflective and critical analysis of the world in front of him, found his position in the middle of the culture and context of life and rose to do the transformation.

Consientization means the process of development in three distinct but interconnected phases, namely magical, naive and critical awareness. Simply put, consientization is the stage of the individual capturing obstacles or contradictions or boundary situations in reality in relation to their presence in the world.

Freire groups community awareness as part of the recipient of education or referred to as students in the social context into three parts. First, magical awareness that is, a public awareness that is not able to see the relationship between one factor with another factor. For example, for the poor, they are unable to see the link between their poverty and the existing political and cultural system. This awareness is characterized by the attitude of accepting reality as a destiny (fatalism) and being silent on the situation. Likewise, in the classroom, students are not able to relate the theories they get to the reality of their daily lives. So what happens is the process of acceptance without being critical and dogmatic in nature.

Second, naïve awareness. This awareness is experienced by those who have seen and understood the causes of chaos in their lives, but they do not have the awareness to rise up and sue or at least try to fight for their rights. This society is apathetic, always looking for safety, either because of fear or because they are not able to organize themselves to become a force in bringing about change.

Third, critical awareness. Awareness that is able to see structural aspects as a source of problems. The structural approach avoids "blaming the victims" but rather analyzes the relationship between reality and social, political, economic, cultural factors and its effects on the state of society. In addition to being able to analyze patterns and reality, this society group is also able to organize themselves as a force to bring change. For people with this critical awareness, that change is not given but must be born from self-awareness to want to change. So it is not surprising that this group of people is always frustrated by a corrupt, unfair, and unfair bureaucratic model for the common good. 
For Freire, the intended critical education is actually to arouse and build students' awareness to become critical citizens too. Education must be able to bring students from magical and naive awareness, toward critical and transformative awareness. Thus, students are able to change themselves and of course also the surrounding environment towards a better direction.

\section{Critical Reflections on Indonesian Education}

It is undeniable that the contribution of Freire thought greatly influenced the development and progress of the concept of critical pedagogy. then, the question is what can we reflect on the concept of Freire education with our education system in Indonesia.

Some things that we need to reflect on in Indonesian Education are, First, just as criticized by Freire, that there are still many Education practices in Indonesia that implement education called Freire as bank style education. The education process is always centered on how the teacher teaches (teacher center) not on how students learn (student center).

Second, wrong character education. In the end, character education has become a major issue in the Indonesian education process. But if you want to be investigated further, the application of character education in schools is stuck on formalism and standardized rules. Character education is considered the same as applying religious teachings. This is a big mistake. So that the character education majadi dogmas that must be obeyed by students, without through critical reflection

Third, religious formalism becomes dominant. Religious doctrines without being filtered by a critical attitude will produce religious fundamentalism. No wonder that many bombers in Indonesia are socially educated people. They are not trained to ask questions and criticize things they think are already established.

Fourth, market orientation education. Educational institutions are like factories producing labor. This is also a big challenge in the issue of Indonesian education, how to produce graduates who are not only oriented to job seekers, but graduates who have values that are able to build the nation's civilization

\section{CONCLUSIONS}

Thus, based on Freire's thinking, some things that can be made references for the Indonesian education system are as follows.

First, education centered on students. It is time for our education system to be student-centered. This means making students part of the educational process itself. So that the concept of full day school, curriculum 2013 or whatever is in the mind of the government must provide the largest portion of student development, because if that does not happen, then the classroom is no more than doctrinal places and memorizing dictates without the space for critical reflection
Second, education based on critical culture. The educational process must provide as much space as possible for students to think, ask questions, and reflect on what they are learning. Critical culture-based education will bring students to the understanding that, there is always a link between the theory that schools can sit on with the realities of life they experience. That the theories obtained in the classroom cannot be separated from the reality, culture and situation of the community. Students are invited to get to know Indonesia and the world more closely. So the generations generated by the Education process are critical generations. because, the big problems facing this country such as drugs, terrorism to corruption can be seen from the results of the less critical education

Third, education is not only market oriented but must also be based on values. That with the development of existing information technology, students can get as much knowledge as possible with internet access, but that knowledge and skills without the values embedded in them will produce a person who is only concerned with himself. Values-based education will advance the nation's civilization.

\section{REFERENCES}

Aulia, Rahma. (2017). Paulo Freire's Humanist Education in the perspective of Islamic education. Thesis: IAIN Raden Intan Lampung.

Durakoğlu, A. P. D. A. (2013). Paulo Freire's perception of dialogue based education. International Journal on New Trends in Education and Their Implications, 4(12), 102-107.

Escobar, Miguel. (2016). Dialogue with Paulo Freire: School of Cunning Capitalism. Yogyakarta: LKis

Firdaus, F. A., \& Mariyat, A. (2017). Humanistic Approach In Education According To Paulo Freire. At-Ta'dib, 12(2), 25-48.

Freire, A. M. A., \& Vittoria, P. (2007). Dialogue on Paulo Freire. Inter-American Journal of Education for Democracy, 1(1), 96-117.

Leonard, P., \& McLaren, P. (Eds.). (2002). Paulo Freire: A critical encounter. Routledge.

Adnan, M. (2018). Paradigma Pendidikan Kritis Dalam Perspektif Pendidikan Islam. CENDEKIA: Jurnal Studi Keislaman, 1(1).

Van Wyk, N. C. (1999). Health education as education of the oppressed. Curationis, 22(4), 29-34.

Freire Paulo. (2008). Education as a Process: Pedagogical Correspondence with Guinea-Bissau Educators. Yogjakarta: Student Library.

Steiner, S. S., Krank, H. M., Bahruth, R. E., \& McLaren, P. (2004). Freireian pedagogy, praxis, and possibilities: Projects for the new millennium. Routledge.

Grollios, G., Giroux, H. A., Gounari, P., \& Macedo, D. (2015). Paulo Freire and the curriculum. Routledge. 
Robandi, B., Kesuma, D., Riyadi, A. R., \& Ibrahim, T. (2017, January). The Profile of Critical Consciousness of Indonesia University of Education Students' on Educational Phenomenon (A Phenomenological Study of Paulo Freire's Pedagogy). In 3rd NFE Conference on Lifelong Learning (NFE 2016). Atlantis Press.

Risakotta, Bernard Adeney. (2001). Paulo Freire Edition. Base Magazine. January - February 2001Collins.

Roberts, Peter. Education, Literacy, and Humanization: Exploring the Work of Paulo Freire. Westport: Bergin \& Garvey.

Smith, William A. (2008).Conscientizacao: Paulo Freire's Educational Objectives, Translated by Agung Prihantoro. Yogyakarta: Student Library. Pruyn, Marc. Paulo Freire and Critical Multicultural Social Studies: One Case from the Reacher Education Borderland. Taboo: The Journal of Culture and Education. 7(1). Spring-Summer. 